\title{
PENGUJIAN KRIM EKSTRAK DAUN KELOR (Moringa oleifera L.) SEBAGAI ANTIBAKTERI
}

\author{
Muthmainna B ${ }^{1}$, Fatma Adjis ${ }^{2}$ \\ 1 *STIKES Nani Hasanuddin Makassar \\ 2*STIKES Nani Hasanuddin Makassar \\ innabaharuddin@gmail.com
}

\begin{abstract}
ABSTRAK
Tanaman kelor merupakan tanaman yang biasanya banyak dimanfaatkan sebagai sayuran. Kelor adalah sayur khas Kaili (Sulawesi tengah). Bagi orang-orang Kaili, penduduk asli kota Palu, sayur kelor salah satu sayuran makanan favorit mereka. Pada penelitian ini, dibuat menjadi tiga konsentrasi 20\%,40\%, dan $80 \%$ serta pembanding yaitu Aquadest sebagai kontrol negatif dan Ciprofloxacin sebagai kontrol positif. Penelitian ini dilakukan dengan menggunakan dengan tiga cawan petri dimana pada setiap cawan diletakkan masing-masing lima rendaman paper disk yang terdiri dari konsentrasi krim ekstrak daun kelor serta perbanding (kontrol negatif dan kontrol positif). Setiap cawan petri berisi konsentrasi krim ekstrak daun kelor yang berbeda-beda. Dengan konsentrasi yang berbeda, maka menghasilkan zona hambat yang berbeda-beda. Zona hambatan ditandai dengan adannya lingkaran bening disekitar paper disk pada masing-masing konsentrasi yang menghambat pertumbuhan terhadap bakteri Staphylococcus aureus. Berdasarkan dari pengukuran yang telah dilakukan dengan menggunakan jangka sorong, diperoleh diameter hambat rata-rata pada konsentrasi $80 \%$ dapat terlihat zona hambat yang paling tinggi yaitu $34,13 \mathrm{~mm}$, pada konsentrasi $20 \%$ sebesar $20,27 \mathrm{~mm}$, pada konsentrasi $40 \%$ sebesar 30,03 mm, sedangkan kontrol negatif Aquadest tidak terlihat adannya zona hambatnya dan kontrol positif Ciprofloxacin diperoleh diameter hambat rata-rata sebesar 43,3 $\mathrm{mm}$.
\end{abstract}

Kata Kunci : Krim Ekstrak Daun Kelor, Staphylococcus Aureus

\section{PENDAHULUAN}

Manusia telah mengenal kosmetik selama berabad-abad. Pada abad ke-19, penggunaan kosmetik mulai mendapat perhatian, tidak hanya untuk kecantikan, tetapi juga untuk kesehatan (Retno, Iswari, 2007).

Kosmetik adalah sediaan atau bahan disiapkan untuk digunakan pada bagian luar tubuh (kulit ari, rambut, kuku, bibir dan alat kelamin luar), gigi dan rongga mulut untuk membersihkan, menambah daya tarik, mengubah penampilan sediaan atau bahan tersebut. membimbing, melindungi dan menjaganya tetap utuh. Dalam. mengobati atau menyembuhkan penyakit (Retno, Iswari, 2007).

Krim adalah sediaan setengah padat berupa emulsi dengan kadar air tidak kurang dari $60 \%$ untuk pemakaian luar (Dirjen POM, 1979).

Penelitian menunjukkan bahwa untuk memudahkan masyarakat dalam menggunakan obat tradisional, telah dilakukan persiapan. Salah satunya adalah sediaan topikal sediaan krim. Penggunaan krim topikal yang mengandung ekstrak etanol krim daun kelor idiharapkan dapat mengurangi peradangan pada kulit (Jurnal Ilmiah Farmasi Farmasyifa Volume 2 No 2, n.d.).

Adapun produk yang mengandung kelor yang ada dipasaran yaitu teh herbal dasar obatobattan, masker wajah, pewarna makanan (Jurnal Ilmiah Farmasi Farmasyifa Volume 2 No 2, n.d.)
Secara umum tanaman kelor yang mempunyai nama di dalam bahasa latin yang disebut Moringa oleifera $\mathrm{L}$ atau ada juga disebut dalam bahasa inggris yaitu drumstick plant merupakan tanaman yang bisa menjadi sayuran yang sarat nutrisinnya dan berbagai jenis kegunannya lainnnya. Pemanfaatan dari daun kelor yaitu menjadi produk olahan yang selama ini kita dapatkan di berbagai tempat contohnya tokotoko, apotek dan lain-lainnya (Erna, 2014).

Tanaman kelor merupakan salah satu jenis tanaman yang biasa digunakan sebagai sayuran.Kelor adalah sayuran tradisional Kaili (Sulawesi Tengah). Sayur kelor merupakan salah satu sayuran favorit masyarakat Kaili yang tinggal di Palu (Dani, 2019). Mereka mengolah kelor, yang umumnya dikenal sebagai ghengan maronggih di daerah Madura, sebagai pendamping makan siang mereka, yang biasa disantap sebagai lalapan dalam kuah (sayur kelor). Akar, daun, dan bijinya dapat digunakan sebagai obat untuk menyembuhkan berbagai penyakit selain sebagai sayuran (Dani, 2019). Saya ingin mempelajari cara menguji daya hambat krim ekstrak daun kelor (Moringa oleifera L.) terhadap bakteri Staphylococcus aureus, oleh karena itu saya mengambil penelitian ini.

Bakteri adalah organisme uniseluler dan nukleoid yang tidak memiliki membran inti, klorofil, saporit, dan parasit, serta pembelahan biner (Agnes, Sri, 2015). Bakteri dengan tiga pembelahan sel, 
seperti Staphylococcus aureus, yang menghasilkan struktur seperti cabang anggur dan bentuk tidak beraturan (Maharani, Pertiwi, 2020).

Penelitian ini merupakan eksperimen laboratorium untuk melihat seberapa efisien Ekstrak Daun Kelor (Moringa oleifera L.) terhadap Staphylococcus aureus. Penelitian ini akan berlangsung di Laboratorium Mikrobiologi Stikes Nani Hasanuddin Makassar yang merupakan bagian dari Jurusan Farmasi. Penelitian ini bertujuan untuk mengetahui apakah krim ekstrak daun kelor (Moringa oleifera L.) memiliki aktivitas antibakteri terhadap kuman Staphylococcus aureus

\section{METODE}

Lokasi, populasi, dan sampel penelitian

Penelitian ini akan berlangsung di Laboratorium Mikrobiologi Stikes Nani Hasanuddin Makassar yang merupakan bagian dari Jurusan Farmasi.Penelitian ini akan berlangsung dari tanggal 7 Juni sampai dengan 7 Juli 2021. Populasi Daun kelor (Moringa oleifar L.) dari Makassar digunakan sebagai populasi penelitian.Sampel Dalam penelitian ini digunakan 50 gram krim ekstrak daun kelor (Moringa oleifera L.) dengan konsentrasi 20\%, 40\%, dan $80 \%$, serta bakteri Staphylococcus aureus.

1. Penyiapan Bakteri Uji

a. Pembuatan Suspensi Bakteri Uji

Untuk mencapai kekeruhan yang sama seperti Mc. Kekeruhan standar Farland, bakteri uji yang idiinokulasi diambil dengan kawat steril dan disuspensikan dalam tabung berisi i $2 \mathrm{ml}$ larutan $\mathrm{HaCl} 0,9$ persen. Setiap jenis mikroorganisme uji menerima perlakuan yang sama.

b. Pembuatan Media Pengujian Setelah lapisan awal mengeras, media uji diproduksi menggunakan metode difusi agar dengan menuangkan $20 \mathrm{~mL}$ NA ke dalam tiga cawan petri untuk lapisan idasar. Tujuh jangkar atau sumur dipasang di permukaan lapisan dasar, diatur sedemikian rupa sehingga jarak antara pengamat tidak bertambah. Suspensi bakteri kemudian dicampur dengan median NA.

2. Pembuatan Larutan Uji Ditimbang 0,2 g, 0,4 g, dan $0,8 \mathrm{~g}$ krim ekstrak daun kelor berturut-turut, dan dilarutkan masing-masing dalam $1 \mathrm{ml}$ akuades menghasilkan larutan uji 20\%, 40\%, dan $80 \% \mathrm{~b} / \mathrm{v}$.

3. Pembuatan Larutan Kontrol Negatif Krim dikombinasikan dengan $100 \mathrm{~mL}$ air suling sebagai kontrol negatif. Kemudian larutan diaduk hingga homogen.

4. Kontrol Positif Ciprofloxacin $500 \mathrm{mg}$ tablet digunakan untuk membuat produk ini. Setelah menghancurkan satu tablet Ciprofloxacin, campurkan dengan aquadest.

5. Pengamatan dan Pengukuran

6. Setelah 1×24 jam inkubasi, dilakukan pengamatan. Area bening menunjukkan kerentanan bakteri terhadap berbagai antibiotik yang akan digunakan sebagai bahan uji, dan diameter zona hambat diklaim.

\section{HASIL PENELITIAN}

Penelitian ini adalah sebagai berikut, berdasarkan penelitian yang dilakukan di Laboratorium Mikrobiologi Farmasi STIKES Nani Hasanuddin Makassar:

Tabel 1 Diameter Zona Hambatan Stahpylococcus aureus Krim Ekstrak Daun Kelor (Moringa oleifera L.).

\begin{tabular}{|l|l|l|l|l|l|l|}
\hline Replikasi & $\begin{array}{l}\text { Kontrol } \\
(-)\end{array}$ & $\begin{array}{c}\text { Kontrol } \\
(+)\end{array}$ & $20 \%$ & $40 \%$ & $80 \%$ & Total \\
\hline I & 0 & 43,2 & 17,10 & 23,60 & 29,8 & 113,7 \\
\hline II & 0 & 44,10 & 22,8 & 35,8 & 35,9 & 138,6 \\
\hline III & 0 & 42,7 & 20,9 & 30,7 & 36,7 & 131 \\
\hline Jumlah & 0 & 130 & 60,8 & 90,1 & 102,4 & 383,3 \\
\hline Rata-rata & 0 & 43,3 & 20,27 & 30,03 & 34,13 & \\
\hline
\end{tabular}

Keterangan :

Kontrol $(-)=$ Aquadest

Kontrol $(+)=$ Ciprofloxacin

\section{PEMBAHASAN}

Kosmetik itu unik karena tampaknya mampu memenuhi semua kebutuhan dasar kecantikan wanita. Sering digunakan oleh konsumen untuk memperjelas identifikasi mereka dengan cara yang dibutuhkan secara sosial. Kosmetik tampaknya menjadi kebutuhan utama bagi sebagian wanita seiring berjalannya waktu. Salah satu kebutuhan vital wanita adalah kosmetik. Wanita tidak bisa lepas dari kosmetik dalam kesehariannya, suka atau tidak suka. Kebanyakan wanita menggunakan body care lotion ini dari pagi hingga malam. Akibatnya, banyak perusahaan berusaha memenuhi tuntutan industri kosmetik dengan berbagai penyempurnaan produk (Susanti, F., \& Gunawan, 2019). Kosmetik dikategorikan menurut Peraturan Menteri Kesehatan Republik Indonesia, berdasarkan modern atau tradisional, dan 
bagaimana penggunaannya pada kulit, termasuk sediaan krim.

Dengan menghitung konsentrasi optimum krim ekstrak daun kelor (Moringa oleifera L.), penelitian ini bertujuan untuk mengetahui uji aktivitas anti bakteri krim ekstrak daun kelor (Moringa oleifera L.) terhadap Staphylococcus aureus. Proses pembuatan krim ekstrak daun kelor diawali dengan pembuatan simplisia yaitu pencucian daun kelor dengan air bersih untuk menghilangkan kotoran, penirisan, dan penjemuran daun di bawah sinar matahari. Setelah daun mengering, mereka siap untuk langkah berikutnya. Simplisia yang telah selesai diekstraksi menggunakan proses maserasi dengan pelarut etanol $70 \%$. Karena $70 \%$ etanol adalah pelarut selektif, diasumsikan bahwa metabolit sekunder dalam simplisia akan diserap terutama ketika menggunakan etanol. Selanjutnya, etanol adalah pelarut polar, imudah ditemukan, tidak beracun yang sering digunakan untuk ekstraksi.

Hasil maserasi berupa ekstrak kental, yang selanjutnya diubah menjadi krim dari ekstrak daun kelor. Aquadest, setil alkohol, gliseril istearat, parafin, petrtalun, titanium dioksida, metil, paraben, propilen glikol, dan propil paraben adalah beberapa bahan kimia lain yang digunakan untuk membuat krim. Variasi konsentrasi tersebut kemudian digunakan sebagai uji aktivitas antibakteri untuk menguji pengaruh aktivitas antibakteri krim ekstrak daun kelor (Moringa oleifera L.) terhadap bakteri Staphylococcus aureus. Ada tiga konsentrasi yang digunakan dalam penelitian ini: $20 \%, 40 \%$, dan $80 \%$, dengan Aquadest sebagai kontrol negatif dan Ciprofloxacin sebagai kontrol positif. Percobaan ini dilakukan dengan menggunakan tiga cawan petri, masing-masing dengan lima paper disk bath dengan konsentrasi krim ekstrak daun kelor dan pembanding (kontrol negatif dan kontrol positif). Krim ekstrak daun kelor hadir dalam berbagai jumlah di setiap cawan petri. Ini menyebabkan zona hambat yang berbeda pada dosis yang berbeda. Pada setiap konsentrasi yang menghentikan pertumbuhan bakteri Staphylococcus aureus, lingkaran berbeda di sekitar kertas cakram menunjukkan zona hambat.

Berdasarkan pengukuran jangka sorong, diameter hambat rata-rata pada konsentrasi 80 persen adalah $34,13 \mathrm{~mm}$, pada konsentrasi 40 persen adalah 30.03 $\mathrm{mm}$, dan pada konsentrasi 20 persen adalah 20,27 $\mathrm{mm}$. Sementara kontrol negatif Aquadest tidak menunjukkan zona hambat, kontrol positif
Ciprofloxacin imemiliki diameter hambat rata-rata 43,3 mm.

Menurut temuan penelitian ini, konsentrasi aktivitas antibakteri $80 \%$ lebih tinggi dari konsentrasi $20 \%$ dan $40 \%$. Ketika diameter rata-rata zona hambat tumbuh seiring dengan konsentrasi krim ekstrak daun kelor, zona hambat menjadi lebih efektif. Artinya semakin tinggi konsentrasi ekstrak daun kelor dalam krim maka semakin banyak zona hambat yang terbentuk. Hal ini sejalan dengan temuan Fatimawati (2016) yang menemukan bahwa semakin tinggi konsentrasi maka semakin banyak senyawa terlarut yang terdapat dalam ekstrak daun kelor. Semakin besar kemampuan bahan uji untuk menekan pertumbuhan bakteri, semakin baik. Laju difusi komponen aktif dipengaruhi oleh konsentrasi krim ekstrak daun kelor; semakin tinggi konsentrasi, semakin cepat difusi, dan dengan demikian semakin kuat daya antibakteri dan semakin lebar diameter zona hambat yang dihasilkan. Karena krim ekstrak daun kelor (Moringa oleifera L.) termasuk senyawa alkaloid, flavonoid yang berfungsi sebagai antibakteri, maka hasil penelitian ini menunjukkan bahwa krim ekstrak daun kelor (Moringa oleifera L.) idapat menghambat bakteri Staphylococcus aureus.

Menurut hasil yang diperoleh, hasil konsentrasi yang diperoleh sesuai dengan literatur, dimana semakin tinggi konsentrasi maka semakin banyak zona hambat yang dicapai, dan bahan kimia yang diperoleh efektif sebagai antibakteri pada ekstrak daun kelor (Moringa oleifera L.).

\section{KESIMPULAN}

Berdasarkan hasil penelitian, diameter rata-rata zona hambat pada konsentrasi 80 persen adalah 34,13 $\mathrm{mm}$, pada konsentrasi 40 persen adalah $30,03 \mathrm{~mm}$, pada konsentrasi 20 persen adalah 20,27, dan tidak ada zona semu di akuades kontrol negatif. Penghambatan dan kontrol ciprofloxacin. Diameter rata-rata hambatan adalah 43,3 $\mathrm{mm}$. Pada konsentrasi $80 \%$, konsentrasi optimal tercapai. Krim ekstrak daun kelor (Moringa oleifera L.) dapat meneka bakteri Staphylococcus aureus pada konsentrasi 20\%, $40 \%$, dan $80 \%$. Zona hambat, yang dicapai pada konsentrasi 80 persen, bagaimanapun, lebih besar.

\section{SARAN}

Penelitian lebih lanjut tentang krim ekstrak daun kelor (Moringa oleifera L.) terhadap bakteri Stahpylococcus aureus diharapkan dapat dilakukan di masa mendatang.

\section{DAFTAR PUSTAKA}

Agnes, Sri, H. (2015). Mikrobiologi Kesehatan. Andi.

Agustina, J, Shoviantari, F, \& Yulianti, N. (2020). Penyuluhan Kosmetik Yang aman dan Notifikasi Kosmetik. Journal Of Community Engagement And Empomerment, Vol.2(1). 
Ahmad, N. (2018). Ekstrak Senyawa Bahan Alam. Deepublish.

Anas, T. (2020). Teknologi Proses Pembuatan Beras Analog Fungsional. Universitas Muhammkadiyah.

Dani, H. (2019). Khasiat Jitu Daun Kelor Dan Sirih Merah Tumpas Penyakit. Laksana.

Devina, C. (2019). Pemanfaatan Biji Kopi Sebagai Antisesulit. CV BUDI UTAMA.

Dina, R. (2019). Buku Ajar Teknologi Kosmetik. CV IRDH.

Dirjen POM. (1979). Farmakope Indonesia Kesehatan Edisi III. Departemen Kesehatan RI.

Elmitra. (2017). Dasar-dasar Farmasetika dan Sediaan Semi Solid. Deepublish.

Erna, N. (2014). Khasiat Dahsyat Daun Kelor. Jendela Sehat.

Ikram, W. (2019). I'm Backpacker Thailand. PUTEH PRESS.

Indan, E. (2003). Mikrobiologi Dan Parasitologi Untuk Akademi Keperawatan Dan Sekolah Tenaga Kesehatan Yang Derajat. CITRA ADITYA BAKTI.

Jurnal Ilmiah Farmasi Farmasyifa Volume 2 No 2. (n.d.). Formulasi Krim Ekstrak Etanol Daun Kelor (Moringa oleifera L).

Jurnal Ilmiah Farmasi UNSRAT Volume 5 No2.Uji Aktivitas Antibakteri Ekstrak Daun Kelor (Moringa oleifera L.) Terhadap Bakteri Esherichia coli Dan Staphylococcus aureus.

Justin. (2015). Sistem Pakar Penentuan Jenis Kulit Wajah Wanita Menggunakan Metode Naive Bayes. Jurnal Sistem Dan Teknologi Informasi, Vol.1, No.

Lisa, R. (2018). Cantik Alami Ala Wanita Jepang,Korea,dan Eropa.

Magdalena AB, Bardi S, Indriyanti W, dan M. S. (2016). Formulasi Krim Antihiper Prigmemtasi Ekstrak Kulit Daun Delima (Punica granatum L). Fakultas Farmasi.

Maharani, Pertiwi, K. (2020). Dinamika Struktur Dinding Sel Bakteri. Jakad Media Publishing.

Nana, S. (2006). Ilmu Pengetahuan Alam (Fisika,Biologi,Kimia). MEDIA PRATAMA.

Nasmi, H. (2021). Pengantar Inhibitor Korosi Alami. CV BUDI UTAMA.

Nia, L. (2020). Ekstrak Buah Belimbing Luwuh (Averrhao blimbi L). CV Jakad Medika Publishing.

Osfar, S. (2019). Teknologi Pengololahan Bahan Ternak. UB Press.

Qurratu, A. (2019). Analisis Ekstrak Daun Kelor (Moringa oleifera L). UB Press.

Retno, Iswari, T. (2007). Buku Pengangan Ilmu Pengetahuan Kosmetik. PT Gramedia Pustaka Utama.

Susanti, F., \& Gunawan, A. C. (2019). Pemharuh Bauran Promosi Dan Harga Terhadap Keputusan Pembelian Produk Kosmetik Maybelline Di Kota Padang. 